\title{
Descriptions of larvae of Megadytes (Coleoptera: Dytiscidae: Dytiscinae): The subgenera Trifurcitus and Megadytes s. str., ground plan of chaetotaxy of the genus and phylogenetic analysis
}

\author{
MARIANO C. MICHAT \\ CONICET, Laboratory of Entomology, DBBE, FCEyN, UBA, Buenos Aires, Argentina; e-mail: marianoide@gmail.com
}

Key words. Diving beetles, Dytiscidae, Cybistrini, Megadytes, Trifurcitus, larva, chaetotaxy, ground plan, phylogenetic relationships

\begin{abstract}
The three larval instars of Megadytes (M.) carcharias Griffini and M. (Trifurcitus) fallax (Aubé) are described and illustrated in detail for the first time, with an emphasis on morphometry and chaetotaxy of the cephalic capsule, head appendages, legs, last abdominal segment and urogomphi. The ground plan of chaetotaxy of the genus Megadytes Sharp is described and illustrated based on three of the four recognised subgenera. First-instar larvae of Megadytes are characterised by the presence of a large number of additional sensilla on almost every part of the body. Primary chaetotaxy of the subgenera (Bifurcitus Brinck based on third instar) is very similar, with few differences including (1) shape of the setae on the anterior margin of the frontoclypeus; (2) presence or absence of a ring of multi-branched setae on distal third of mandible; and (3) number of setae on the urogomphus. A cladistic analysis of Dytiscidae, based on 169 larval characters and 34 taxa, indicates that: (1) Trifurcitus Brinck deserves generic status; (2) Cybistrini are not closely related to Hydroporinae; (3) the absence of a galea in Cybistrini is a secondary loss independent of that in Hydroporinae; (4) Cybistrini are well supported by many characters (including several aspects of first-instar chaetotaxy).
\end{abstract}

\section{INTRODUCTION}

A previous study (Michat, 2006) of the larval morphology of the diving-beetle genus Megadytes Sharp (Dytiscinae: Cybistrini) tested the hypothesis of a monophyletic origin of this genus and provided a key for the identification of the subgenera. At that time, however, the first instar of only one species [M. (Paramegadytes) glaucus (Brullé)] was available for study, which prevented a broad analysis of the primary chaetotaxy. In particular, any attempt to establish a ground plan for the chaetotaxy of the genus was deemed to be premature. Members of the tribe Cybistrini are particularly interesting from a chaetotaxic perspective because their larvae have many additional sensilla (Nilsson, 1988; Michat, 2006) which, to a certain degree, obscure the pattern of ancestral sensilla that is commonly observed in members of other dytiscid subfamilies and tribes of Dytiscinae. As demonstrated recently, primary chaetotaxy is an important source of characters both for phylogenetic and diagnostic purposes (Alarie et al., 2007, 2009; Michat, 2006, 2008; Michat \& Alarie, 2009; Michat \& Archangelsky, 2009; Michat \& Torres, 2006, 2008, 2009; Michat et al., 2007). The development of a system of nomenclature for the primary sensilla of first-instar larvae of Dytiscidae resulted in great progress in the exploration of an extensive set of characters that is phylogenetically and diagnostically very useful.

In this contribution the first-instar larvae of species belonging to other two subgenera (Trifurcitus Brinck and Megadytes s. str.) are described, which together with the previously described first instar of Paramegadytes Trémouilles \& Bachmann (Michat, 2006) increase to three the number of subgenera for which the first-instar larvae are known. A review of previous knowledge on the larvae of Megadytes can be found in Michat (2006). Also, descriptions of the mature larvae of $M$. giganteus (Laporte) and M. latus (Fabricius) were presented by Ferreira Jr. (2000) and Ferreira Jr. et al. (2006), respectively. Based on the detailed generic description of the larvae of Megadytes presented in Michat (2006), I present here diagnosis, descriptions and illustrations of the three larval instars of $M$. (M.) carcharias Griffini and $M$. (T.) fallax (Aubé). Also, the ground plan of chaetotaxy of the genus is described based on three of the four subgenera, and interesting features are compared and discussed.

The finding of the first-instar larvae of members of Trifurcitus and Megadytes s. str. is also interesting because it allows a reanalysis of previous results (Michat, 2006), which were based only on the mature larva, but now can also include characters of first and second instars. Though the monophyly of Dytiscinae, including Cybistrini, is well supported by both adult (Miller, 2000, 2001, 2003; Miller et al., 2007) and larval (Michat, 2006) characters, recent studies based on DNA sequence data controversially indicate a position of Cybistrini outside the Dytiscinae, more closely related to Hydroporinae and Laccophilinae (Ribera et al., 2008; see also Miller, 2003). On the other hand, previous results (Michat, 2006) indicate that Megadytes is not monophyletic, with members of the subgenus Trifurcitus placed outside this genus and characterised by a subtriangular head and evenly curved mandibles, that lack a ring of multi-branched setae on the distal third, which contradicts the results of a previous study based on adult and molecular data (Miller et al., 2007). In the light 
of this evidence, the primary objectives of the phylogenetic analysis presented here are: (1) to re-evaluate, using a larger larval data set, if the hypotheses of monophyly for the Cybistrini but not for Megadytes are corroborated, and (2) to test, based on a broader sampling of larval characters and taxa, the phylogenetic relationships of the Cybistrini within Dytiscidae.

\section{MATERIAL AND METHODS}

Specimens were cleared in lactic acid, dissected and mounted on glass slides in polyvinyl-lacto-glycerol. Observations (at magnifications up to $1,000 \times$ ) and drawings were made using an
Olympus CX31 compound microscope equipped with a camera lucida. Drawings were scanned and digitally edited. The material is held in the larval collection of M.C. Michat (Laboratory of Entomology, Buenos Aires University, Argentina).

\section{Morphometric and chaetotaxic analyses}

The methods and terms used in the present paper follow those employed in a previous paper on the larval morphology and chaetotaxy of Megadytes (Michat, 2006). The reader is also referred to Nilsson (1988) and Michat \& Alarie (2009) for a complete list and additional explanations of the terms used in the present study.

TABLE 1. Taxa coded for cladistic analysis.

\begin{tabular}{|c|c|c|}
\hline Taxon & Species & Source \\
\hline ASPIDYTIDAE & Aspidytes niobe Ribera, Beutel, Balke \& Vogler, 2002 & Alarie \& Bilton, 2005 \\
\hline \multicolumn{3}{|l|}{ DYTISCIDAE } \\
\hline \multicolumn{3}{|l|}{ AgABInAE } \\
\hline Agabini & Leuronectes curtulus Régimbart, 1899 & - \\
\hline \multicolumn{3}{|l|}{ Colymbetinae } \\
\hline Colymbetini & Rhantus signatus (Fabricius, 1775) & - \\
\hline \multicolumn{3}{|l|}{ CopelatinaE } \\
\hline Copelatini & Copelatus longicornis Sharp, 1882 & - \\
\hline \multicolumn{3}{|l|}{ COPTOTOMINAE } \\
\hline Coptotomini & Coptotomus interrogatus (Fabricius, 1801) & Barman, 2004 \\
\hline \multicolumn{3}{|l|}{ DYTISCINAE } \\
\hline Aciliini & Thermonectus succinctus (Aubé, 1838) & - \\
\hline Aubehydrini & Notaticus fasciatus Zimmermann, 1928 & - \\
\hline \multirow{10}{*}{ Cybistrini } & Cybister lateralimarginalis (De Geer, 1774) & Fiori, 1949; De Marzo, 1979 \\
\hline & Megadytes $(B$.$) giganteus (Laporte, 1835)$ & Ferreira Jr., 1993 \\
\hline & Megadytes (B.) magnus Trémouilles \& Bachmann, 1980 & - \\
\hline & Megadytes (M.) carcharias Griffini, 1895 & - \\
\hline & Megadytes (M.) marginithorax (Perty, 1830) & Ferreira Jr., 1995 \\
\hline & Megadytes (P.) australis (Germain, 1854) & - \\
\hline & Megadytes (P.) glaucus (Brullé, 1838) & - \\
\hline & Megadytes (T.) fallax (Aubé, 1838) & - \\
\hline & Megadytes $(T$.$) robustus (Aubé, 1838)$ & - \\
\hline & Onychohydrus scutellaris (Germar, 1848) & Watts, 1964 \\
\hline Dytiscini & Dytiscus harrisii Kirby, 1837 & - \\
\hline Eretini & Eretes australis (Erichson, 1842) & Miller, 2002 \\
\hline Hydaticini & Hydaticus tuyuensis Trémouilles, 1996 & - \\
\hline Hyderodini & Hyderodes shuckardi Hope, 1838 & Bertrand, 1934; Watts, 1964 \\
\hline \multicolumn{3}{|l|}{ HYDROPORINAE } \\
\hline Bidessini & Anodocheilus maculatus Babington, 1841 & - \\
\hline \multirow[t]{3}{*}{ Hydroporini } & Canthyporus kenyensis Bilardo \& Sanfilippo, 1979 & Shaverdo \& Alarie, 2006 \\
\hline & Hydroporus columbianus Fall, 1923 & Alarie \& Harper, 1990; Alarie et al., 1990a; Alarie, 1991a,b \\
\hline & Laccornellus lugubris (Aubé, 1838) & - \\
\hline Hydrovatini & Hydrovatus caraibus Sharp, 1882 & - \\
\hline Hygrotini & Hygrotus sayi J. Balfour-Browne, 1944 & Alarie \& Harper, 1990; Alarie et al., 1990a,b; Alarie, 1991a \\
\hline Hyphydrini & Desmopachria concolor Sharp, 1882 & - \\
\hline Laccornini & Laccornis latens (Fall, 1937) & Alarie \& Harper, 1990; Alarie et al., 1990a; Alarie, 1989, 1991a \\
\hline Methlini & Celina parallela (Babington, 1841) & - \\
\hline Vatellini & Vatellus haagi Wehncke, 1876 & - \\
\hline \multicolumn{3}{|l|}{ LACCOPHILINAE } \\
\hline Laccophilini & Laccophilus obliquatus Régimbart, 1889 & - \\
\hline \multicolumn{3}{|l|}{ LANCETINAE } \\
\hline Lancetini & Lancetes marginatus (Steinheil, 1869) & - \\
\hline \multicolumn{3}{|l|}{ MATINAE } \\
\hline Matini & Matus bicarinatus (Say, 1823) & Alarie et al., 2001 \\
\hline
\end{tabular}




\section{Phylogenetic analysis}

The phylogenetic relationships of members of the tribe Cybistrini with other dytiscid groups were analyzed cladistically using the program TNT (Goloboff et al., 2008) and the character set provided by the larval morphology and chaetotaxy. A broad range of taxa was included, comprising members of nine of the 10 recognised dytiscid subfamilies (Nilsson, 2001) (Table 1). The subfamily Hydrodytinae was not included because their larvae are unknown. Data for most species were scored directly from observations on specimens and data for the remaining species from the literature. In order to avoid the problem of comparing different semaphoronts (see Meier \& Lim, 2009), in the codification of each character the same instars were compared, based on the fact that Dytiscidae larvae pass through three instars distinguishable by the presence of egg bursters (instar I), the presence of conspicuous spiracular openings on mesothorax and abdominal segments I-VII (instar III), or the absence of both characters (instar II). The tree was rooted in Aspidytidae (another family of aquatic Adephaga) to allow the dytiscid taxa to vary freely, thus testing the relationships of Cybistrini with the other dytiscid groups. All characters were treated as unordered and equally weighted. Multistate characters were treated as non-additive. A heuristic search was implemented using "tree bisection reconnection" as an algorithm, with 200 replicates and saving 100 trees per replication (previously setting "hold 20,000 "). Bremer support values were calculated using the commands "hold 20,000", "sub n" and "bsupport", where " $n$ " is the number of extra steps allowed. The process was repeated increasing the length of the suboptimal cladograms by one step, until all Bremer values were obtained (Kitching et al., 1998). Jackknife values were calculated using 2,000 replicates and $\mathrm{P}$ $($ removal probability $)=36$.

\section{RESULTS}

Michat (2006) provides a detailed description of the larvae of the genus Megadytes. For this reason, most characters commonly recognised in all species of the genus are not included in the present paper and only diagnostic or interesting features are mentioned.

\section{Megadytes (Megadytes) carcharias Griffini}

Material. Eight specimens of instar I, three of instar II and three of instar III were used for the descriptions. The larvae were collected in association with adults at the following locality: Argentina, Chaco Province, El Cachapé refuge, Qia creek, 3.-4.xii.2008. Larvae and adults were collected among the marginal vegetation in shallow areas of the creek. The identification of the larvae is based on the following: (1) there were no other species of the subgenus Megadytes s. str. in the area where the larvae were collected [except M. laevigatus (Olivier), see below]; (2) tens of adults were taken from the creek along with the larvae, all of them belonging to $M$. carcharias except for one specimen of $M$. laevigatus (a much smaller species that can be ruled out because of its size); (3) the range of head width of the larvae described is smaller than that of M. marginithorax (Perty) (Ferreira Jr., 1995), the only other Megadytes s. str. whose distribution includes the collecting site.

Diagnosis. Cephalic capsule markedly longer than broad (instars I-III) (Figs 1, 3); lateral projections on frontoclypeus single, triangular (instars I-III) (Figs 1, 3); distal third of mandible bearing a ring of long multibranched setae (instars I-III) (Figs 1, 11); distal part of labial palpomere 2 about three times as long as basal part (instar I) (Figs 17-18), about 1.5 times as long as basal
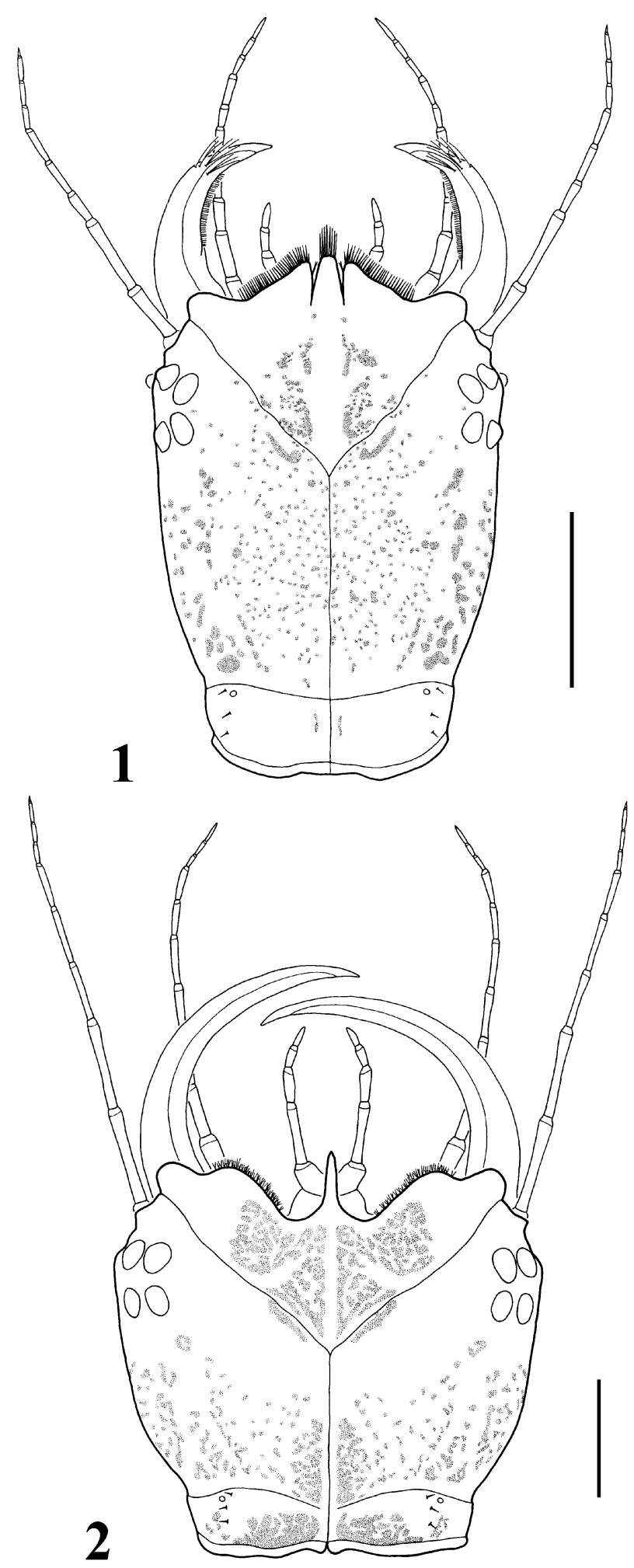

Figs 1-2. Head of third-instar larva of species of Megadytes, dorsal aspect. $1-$ M. carcharias; $2-$ M. fallax. Setation omitted in order to emphasize colour pattern. Scale bars $=1.50 \mathrm{~mm}$.

part (instar II), or about as long as basal part (instar III) (Fig. 1); ratios A3/A1, MP3/MP2 and LP2/LP1 (instars I-III) (Table 2); notches between medial and lateral projections on frontoclypeus very narrow (instars II-III) 

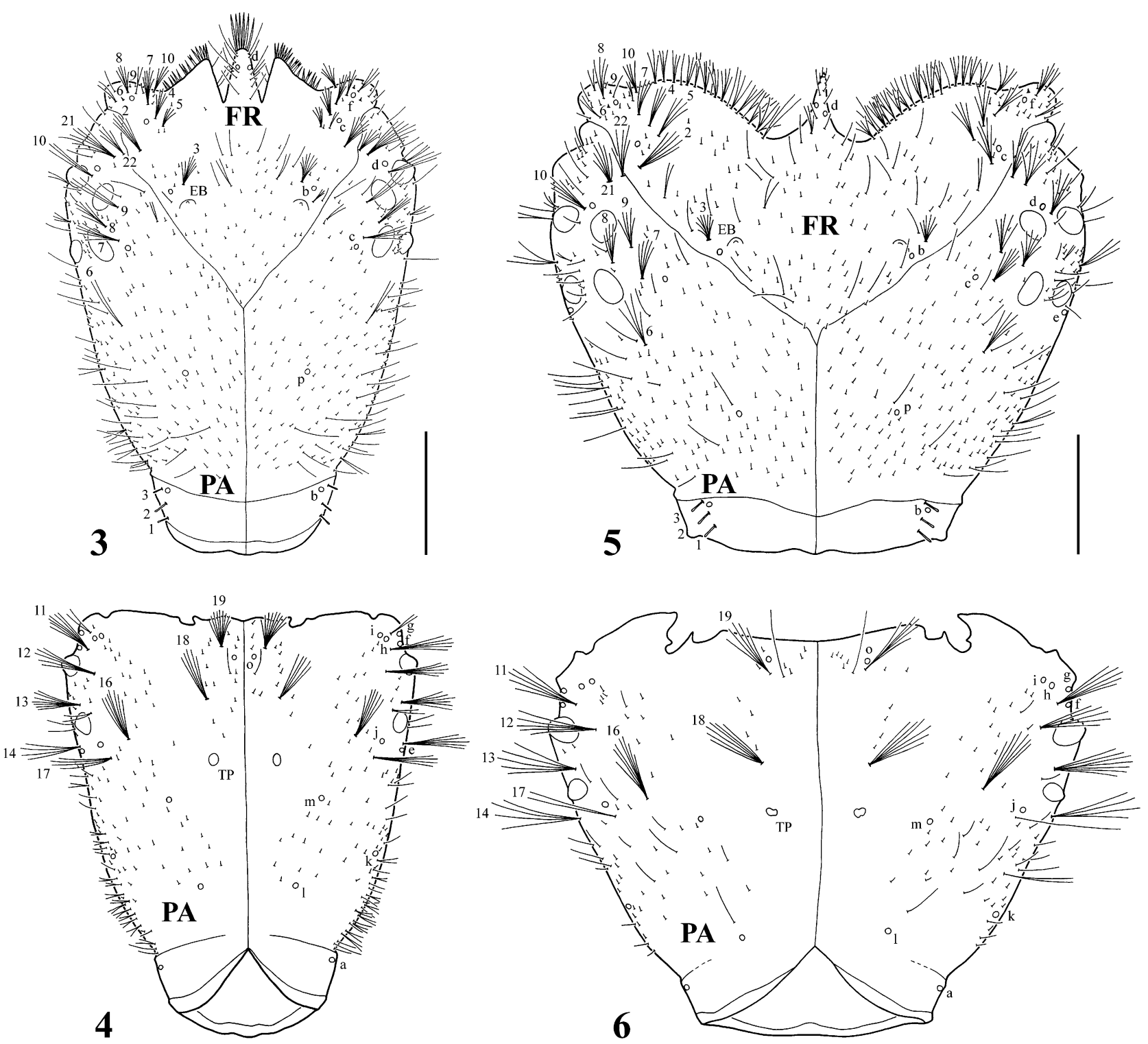

Figs 3-6. Cephalic capsule of first-instar larva of species of Megadytes. 3-4 - M. carcharias: 3 - dorsal aspect; 4 - ventral aspect. 5-6-M. fallax: 5 - dorsal aspect; 6 - ventral aspect. EB - egg burster; TP - tentorial pit. Scale bars $=0.50 \mathrm{~mm}$.

(Fig. 1); distal part of antennomere 1 longer than basal part (instar III) (Fig. 1); measurements and ratios that characterise the body shape are shown in Table 2.

\section{Description of colour}

Instar I. Frontoclypeus pale yellow except for some brown maculae on central portion, medial to egg bursters; parietal pale yellow ventrally, light brown dorsally except for pale yellow areas around stemmata and posterior to occipital suture, light brown area with several small brown maculae; antenna light brown except for basal half of antennomere 3 pale yellow; mandible pale yellow except for distal portion light brown; maxilla light brown except for basal half of palpomere 3 pale yellow; labium pale yellow; thoracic tergites pale yellow, protergite with one brown macula on each side of anterior half, mesoand metatergite with four brown maculae on anterior margin and one on each lateral margin; abdominal tergites I-VI pale yellow with four brown maculae on anterior margin and one light brown macula on posterolateral angle; abdominal tergites VII-VIII pale yellow except for distal third of segment VIII light brown and two brown maculae on anterior margin; membranous parts pale; legs pale yellow except trochanter, tibia and tarsus light brown; urogomphus light brown.

Instar II. As instar I except: small brown maculae on cephalic capsule more numerous; head appendages pale yellow to light brown except for distal portion of mandible and apices of antenna and maxilla darker; thoracic and abdominal tergites with numerous small brown maculae on the surface; legs evenly pale yellow.

Instar III (Fig. 1). As instar II except: darker in general; small brown maculae on cephalic capsule, thoracic and abdominal tergites more numerous; legs evenly light brown; urogomphus brown. 
TABLE 2. Measurements and ratios for the three larval instars of two species of Megadytes. Three specimens of each instar were measured.

\begin{tabular}{|c|c|c|c|c|c|c|}
\hline \multirow{2}{*}{ Measure } & \multicolumn{3}{|c|}{ Megadytes carcharias } & \multicolumn{3}{|c|}{ Megadytes fallax } \\
\hline & Instar I & Instar II & Instar III & Instar I & Instar II & Instar III \\
\hline TL (mm) & $13.70-22.80$ & $24.00-28.00$ & $39.50-49.00$ & $23.00-31.00$ & $31.50-46.00$ & $44.00-53.00$ \\
\hline MW (mm) & $1.00-1.90$ & $1.90-2.70$ & $2.90-4.00$ & $1.70-2.70$ & $3.00-4.20$ & $5.20-6.80$ \\
\hline $\mathrm{HL}(\mathrm{mm})$ & $2.05-2.08$ & $2.98-3.06$ & $4.44-4.46$ & $2.00-2.03$ & $3.30-3.34$ & $4.98-5.35$ \\
\hline $\mathrm{HW}(\mathrm{mm})$ & $1.38-1.39$ & $2.00-2.09$ & $2.98-3.13$ & $2.23-2.28$ & $3.60-3.68$ & $5.30-5.50$ \\
\hline FRL (mm) & $1.00-1.09$ & $1.40-1.46$ & $1.90-2.00$ & $1.14-1.15$ & $1.73-1.80$ & $2.53-2.75$ \\
\hline OCW (mm) & $0.60-0.63$ & $1.03-1.08$ & $1.88-2.00$ & $0.99-1.09$ & $1.85-2.08$ & $3.15-3.29$ \\
\hline HL/HW & $1.48-1.51$ & $1.47-1.49$ & $1.42-1.50$ & $0.88-0.91$ & $0.91-0.92$ & $0.94-0.97$ \\
\hline HW/OCW & $2.20-2.29$ & $1.93-1.95$ & $1.56-1.59$ & $2.07-2.25$ & $1.77-1.95$ & $1.61-1.71$ \\
\hline $\mathrm{COL} / \mathrm{HL}$ & $0.47-0.51$ & $0.51-0.53$ & $0.55-0.57$ & $0.43-0.44$ & $0.45-0.48$ & $0.49-0.50$ \\
\hline FRL/HL & $0.49-0.52$ & $0.47-0.49$ & $0.43-0.45$ & $0.56-0.58$ & $0.52-0.55$ & $0.50-0.51$ \\
\hline $\mathrm{A} / \mathrm{HW}$ & $1.32-1.38$ & $1.12-1.15$ & $0.94-1.00$ & $1.21-1.23$ & $1.02-1.06$ & $0.90-1.00$ \\
\hline $\mathrm{A} 3 / \mathrm{A} 1$ & $0.71-0.72$ & $0.60-0.62$ & $0.48-0.54$ & $0.55-0.58$ & $0.44-0.47$ & $0.35-0.39$ \\
\hline A4/A3 & $0.15-0.17$ & $0.12-0.14$ & $0.10-0.11$ & $0.12-0.16$ & $0.09-0.10$ & $0.07-0.08$ \\
\hline $\mathrm{A} 3{ }^{\prime} / \mathrm{A} 4$ & $0.93-0.94$ & $0.71-0.93$ & $0.86-0.93$ & $0.61-0.80$ & $0.67-0.77$ & $0.75-0.77$ \\
\hline MNL/MNW & $3.09-3.29$ & $2.82-3.00$ & $2.92-3.13$ & $4.25-4.45$ & $4.02-4.65$ & $3.95-4.08$ \\
\hline MNL/HL & $0.41-0.42$ & $0.40-0.41$ & $0.40-0.42$ & $0.85-0.86$ & $0.79-0.81$ & $0.70-0.77$ \\
\hline PPF/MP1 & $0.33-0.35$ & $0.35-0.37$ & $0.40-0.44$ & $0.33-0.35$ & $0.36-0.39$ & $0.36-0.40$ \\
\hline $\mathrm{A} / \mathrm{MP}$ & $1.33-1.35$ & $1.37-1.39$ & $1.42-1.46$ & $1.40-1.48$ & $1.43-1.47$ & $1.43-1.51$ \\
\hline MP3/MP2 & $1.57-1.64$ & $1.45-1.49$ & $1.32-1.43$ & $0.95-1.00$ & $0.72-0.80$ & $0.70-0.73$ \\
\hline MP/LP & $2.46-2.49$ & $2.25-2.41$ & $2.08-2.09$ & $2.26-2.33$ & $2.14-2.34$ & $2.02-2.07$ \\
\hline LP2/LP1 & $1.02-1.04$ & $0.86-0.89$ & $0.68-0.74$ & 0.64 & $0.55-0.57$ & $0.43-0.45$ \\
\hline L3 (mm) & $4.49-4.65$ & $6.03-6.18$ & $8.38-8.69$ & $5.73-5.87$ & $8.16-8.49$ & $12.16-12.54$ \\
\hline $\mathrm{L} 3 / \mathrm{L} 1$ & $1.20-1.21$ & $1.21-1.22$ & $1.21-1.25$ & $1.25-1.28$ & $1.23-1.27$ & $1.25-1.26$ \\
\hline $\mathrm{L} 3 / \mathrm{L} 2$ & $1.10-1.12$ & $1.10-1.11$ & $1.10-1.13$ & $1.11-1.13$ & $1.11-1.14$ & $1.11-1.13$ \\
\hline L3/HW & $3.24-3.39$ & $2.93-3.05$ & $2.69-2.92$ & $2.55-2.62$ & $2.27-2.36$ & $2.25-2.33$ \\
\hline $\mathrm{L} 3(\mathrm{CO} / \mathrm{FE})$ & $0.99-1.03$ & $0.97-1.04$ & $0.98-1.02$ & $0.94-0.98$ & $0.97-1.01$ & $1.01-1.05$ \\
\hline L3 (TI/FE) & $0.68-0.75$ & $0.67-0.68$ & $0.65-0.68$ & $0.65-0.68$ & $0.59-0.63$ & $0.56-0.60$ \\
\hline L3 (TA/FE) & $0.76-0.84$ & $0.68-0.70$ & $0.59-0.63$ & $0.77-0.80$ & $0.64-0.67$ & $0.52-0.58$ \\
\hline L3 (CL/TA) & $0.39-0.42$ & $0.37-0.40$ & $0.35-0.38$ & $0.39-0.40$ & $0.33-0.37$ & $0.35-0.38$ \\
\hline LAS (mm) & $3.36-3.54$ & $4.14-4.53$ & $6.08-6.34$ & $5.04-5.11$ & $7.65-7.80$ & $10.35-11.03$ \\
\hline LAS/HW & $2.43-2.57$ & $2.07-2.17$ & $1.94-2.13$ & $2.21-2.27$ & $2.12-2.15$ & $1.95-2.00$ \\
\hline $\mathrm{U}(\mathrm{mm})$ & $0.01-0.02$ & $0.02-0.03$ & $0.03-0.04$ & $0.03-0.04$ & $0.04-0.05$ & $0.06-0.09$ \\
\hline
\end{tabular}

\section{Megadytes (Trifurcitus) fallax (Aubé)}

Material. Ten specimens of instar I, three of instar II and three of instar III were used for the descriptions. The larvae were collected in association with adults at the following locality: Argentina, Corrientes Province, Mburucuyá National Park, 5.-9.xi.1997, large permanent ponds of different sizes, with clear water, muddy bottom with organic debris and abundance of emergent and floating vegetation. The identification of the larvae is based on the following: (1) there are only two species of Trifurcitus in Argentina, M. robustus (Aubé) and M. fallax, the first is considerably larger than the second; therefore, the larvae of both species can be easily separated by size (for example head width); (2) the mature larva of M. robustus is described by Michat (2006) and differs from M. fallax in having short and stout setae on the anterior margin of frontoclypeus (in M. fallax the setae are setiform and multi-branched); (3) $M$. robustus was not collected at the locality where the larvae were taken.

Diagnosis. Cephalic capsule slightly broader than long (instars I-III) (Figs 2, 5); medial projection on frontoclypeus sharp, almost glabrous apically (instars I-III)
(Figs 2, 5); lateral projections on frontoclypeus broad, flattened (instars I-III) (Figs 2, 5); distal third of mandible lacking a ring of long multi-branched setae (instars I-III) (Figs 2, 12); median process on prementum not bifid apically (instars I-III) (Figs 19-20); basal part of labial palpomere 1 longer than distal part (instars I-III) (Figs 2, 19-20); distal part of labial palpomere 2 about twice as long as basal part (instar I) (Figs 19-20), or about as long as basal part (instars II-III) (Fig. 2); mandible long, slender, almost evenly curved (instars II-III) (Fig. 2) or with the distal third somewhat more projected inwards (instar I) (Fig. 12); ratios A3/A1, MP3/MP2 and LP2/LP1 (instars I-III) (Table 2); abdominal sclerites I and VII without an anterotransverse carina (instars II-III); meso- and metatergite without an anterotransverse carina (instar I); parts of antennomere 1 subequal in length (instar III) (Fig. 2); measurements and ratios that characterise the body shape are shown in Table 2 . 

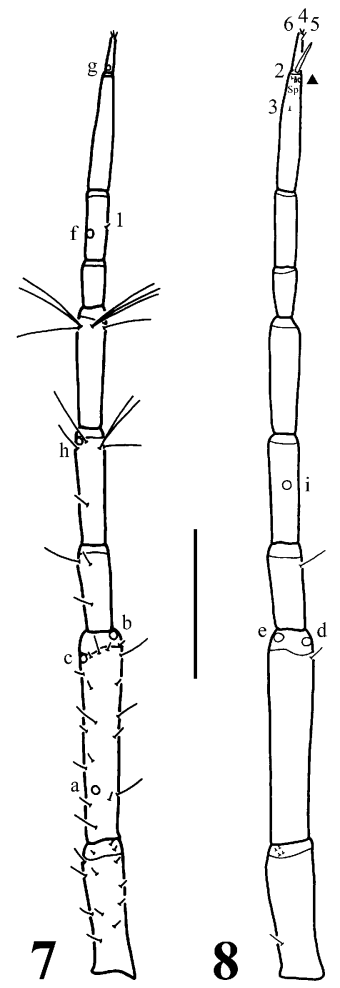

AN

Figs 7-10. Antenna of first-instar larva of species of Megadytes. 7-8 - M. carcharias: 7 - dorsal aspect; 8 - ventral aspect. 9-10 - M. fallax: 9 - dorsal aspect; 10 - ventral aspect. Sp spinula. Solid triangles indicate additional pores. Scale bars $=$ $0.30 \mathrm{~mm}$.

\section{Description of colour}

Instar I. Cephalic capsule evenly pale brown; head appendages pale brown except antennomere 4 and apices of antennomere 3 , maxillary palpomere 3 , and labial palpomere 2 brown; thoracic tergites pale yellow, protergite with one brown macula on each side of anterior half, meso- and metatergite with four brown maculae on anterior margin, one on each lateral margin, and one (diffuse) on posterior margin; abdominal tergites I-VI pale yellow with four brown maculae on anterior margin and one pale brown macula on posterolateral angle; abdominal tergite VII pale yellow with two brown maculae on anterior margin; abdominal segment VIII pale brown, distal half somewhat darker; membranous parts pale; legs evenly pale yellow; urogomphus brown.

Instar II. As instar I except: cephalic capsule pale brown with numerous small dark brown maculae on the frontoclypeus (covering the whole surface except the anterolateral corners) and the parietals (covering the dorsal surface and the laterals of ventral surface); thoracic tergites pale brown with numerous dark brown maculae all over the surface; abdominal terga I-VI variegated, with pale yellow and pale brown longitudinal bands; legs evenly pale brown.

Instar III (Fig. 2). As instar II except: apex of labial palpomere 2 of same colour as the rest of the segment; abdominal segment VII pale brown.
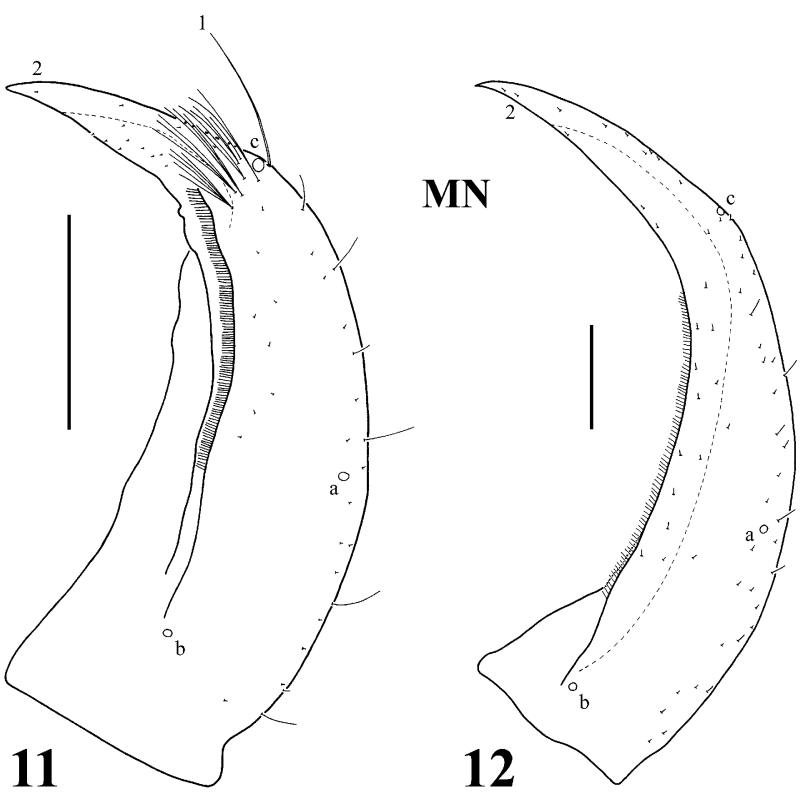

Figs 11-12. Mandible of first-instar larva of species of Megadytes, dorsal aspect. $11-$ M. carcharias; $12-$ M. fallax. Scale bars $=0.25 \mathrm{~mm}$.

\section{Ground plan of chaetotaxy of Megadytes Sharp}

Hypotheses of homology for the setae and pores present in the genus Megadytes are presented based on the examination of members of three of the four subgenera currently recognized: Trifurcitus and Megadytes s. str. (described in the present paper), and Paramegadytes (described in Michat, 2006). On this basis, the ground plan of primary chaetotaxy for the genus is established. Setae and pores present in the larvae of Megadytes were named by comparison with those of members of other tribes of the subfamily Dytiscinae for which the primary chaetotaxy is described in detail (Michat \& Torres, 2005, 2006; Michat \& Alarie, 2009). Homologies were established using the criterion of similarity of position (Wiley, 1981). As stated above, larvae of Megadytes characteristically have numerous additional sensilla that obscure the establishment of homologies with the ancestral systems in other tribes of Dytiscinae. For this reason, an additional criterion for homology was implemented based on the fact that larvae of Megadytes are characterised by the presence of multi-branched setae (setae that are split into two or more branches at a certain distance from the base), and the distribution of these setae on some structures (e.g. cephalic capsule, last abdominal segment) is very similar to the distribution of the ancestral setae in other Dytiscinae. The presence of a multi-branched seta was considered as an argument for homology when more than one seta present in Megadytes is potentially homologous with a given seta in other dytiscine genera. The ancestral chaetotaxy pattern thus established for Megadytes is in good agreement with that observed in other Dytiscinae larvae (Michat \& Torres, 2005, 2006; Michat \& Alarie, 2009). For the urogomphus, homology of the setae and pores was not attempted because of the strongly modified shape of this structure in Megadytes. 


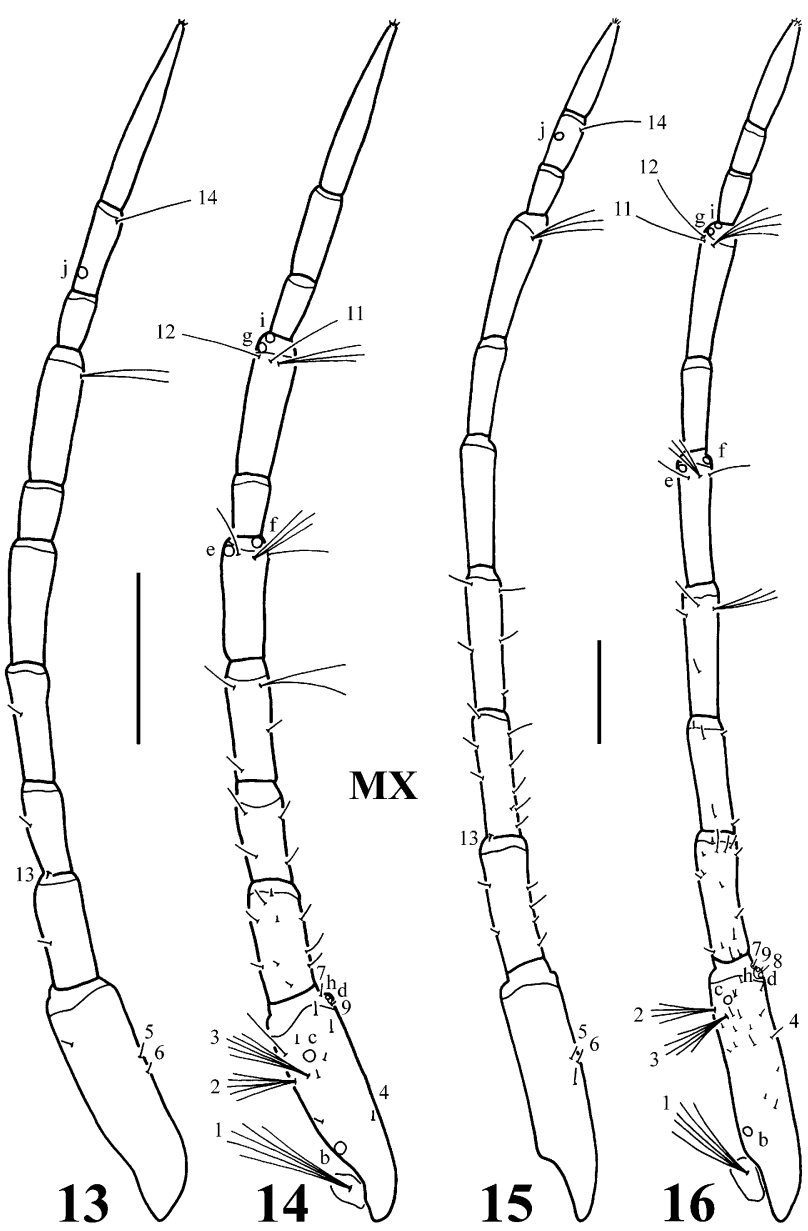

Figs 13-16. Maxilla of first-instar larva of species of Megadytes. 13-14 - M. carcharias: 13 - dorsal aspect; 14 - ventral aspect. 15-16 - M. fallax: 15 - dorsal aspect; 16 - ventral aspect. Scale bars $=0.25 \mathrm{~mm}$.

Primary chaetotaxy proves to be remarkably similar among the subgenera, with few differences in ancestral sensilla and a large number of additional sensilla on almost all the structures examined. In the following, a summary of the primary setae and pores present in Megadytes larvae is presented, and differences among the subgenera are remarked upon when appropriate.

Frontoclypeus (Figs 3, 5). Setae FR2-5, FR7-8 and FR10 multi-branched. Setae FR6 and FR9 minute. Pore FRd located on the medial projection. Presence of numerous additional setae on the surface.

Parietal (Figs 3-6). Setae PA6-14, PA16-19 and PA21-22 multi-branched. Presence of numerous additional setae on the surface, some multi-branched on lateral margins.

Antenna (Figs 7-10). Setae AN1-3 minute. Antennomeres 1 and 2 with numerous additional setae, some on antennomere 2 multi-branched.

Mandible (Figs 11-12). MN1 obscured in Trifurcitus by the presence of additional setae. Numerous additional setae on dorsal and ventral surfaces. Distal third in Paramegadytes and Megadytes s. str. bearing a ring of long multi-branched setae.
Maxilla (Figs 13-16). Setae MX1-3 multi-branched. Setae MX8-9 and pores MXd and MXh inserted on the stipes (seta MX8 in Megadytes s. str. was not found nor was it possible to determine if it is really absent). Seta MX10 obscured by the presence of additional setae. Stipes, palpifer and palpomere 1 with several additional setae, $2-3$ on palpomere 1 multi-branched. Palpomere 2 with two additional multi-branched setae apically.

Labium (Figs 17-20). Number of setae on anterodorsal surface of prementum variable: in Paramegadytes four setae were consistently observed (LA3-5 and LA8), whereas in Trifurcitus there are 2-4 setae; in Megadytes s. str. three setae were consistently observed. Setae LA2, LA6 and LA11 multi-branched. Setae LA10 and LA12 minute. Palpomere 1 with several additional setae, two on the distal portion multi-branched.

Leg (Figs 21-24). Setae FE4-5 present on posteroapical margin. Setae FE6, TI1 and frequently TA1 multibranched. Setae CO7, CO18, TR2-3, FE9-10 and TI6-7 obscured by the presence of additional setae. Presence of numerous additional setae on coxa, trochanter, femur, and anterior surface of tibia and tarsus. Posterior surface of coxa with several additional pores.

Last abdominal segment (Figs 25-28). Setae AB2-3, AB5, AB9, AB11 and AB15 multi-branched. Setae AB6-7 minute. Seta AB4 and pore ABa obscured by the presence of additional setae and pores respectively. Presence of numerous additional setae on dorsal and ventral surfaces.

Urogomphus (Figs 29-30). In Paramegadytes and Trifurcitus there are a maximum of seven setae; in some specimens only six setae could be observed, but it was not possible to determine if the seventh seta is really absent. In Megadytes s. str. there are consistently six setae, this number appears to be the maximum for this subgenus. A single pore was present in the three subgenera, but in some specimens it was not possible to find it. The extremely small size of the urogomphi in Megadytes makes the observation of the sensilla very difficult.

\section{Character analysis}

A total of 169 characters derived from the larval morphology and chaetotaxy were included, of which 125 were coded as binary and 44 as multistate (Appendix 1). The analysis of the data matrix (Appendix 2) using TNT resulted in 34 most parsimonious trees of 483 steps $(\mathrm{CI}=$ 0.47 ; RI $=0.78$ ). The trees differed in the relative positions of the dytiscine genera and in the relative positions of some genera within Cybistrini. For this reason, the strict consensus was calculated, in which several genera collapsed in polytomies (Fig. 31). Hydroporinae, Dytiscinae and Cybistrini came out as the best supported clades in the analysis. However, the relationships within these lineages were in general poorly supported as were the basal relationships of the non-hydroporine clade (Fig. 31). The consensus revealed a basal split into two large clades, one corresponding to the subfamily Hydroporinae and the other including the remaining subfamilies. Within this last clade, Dytiscinae (including Cybistrini) was resolved as monophyletic in agreement with Miller (2000, 

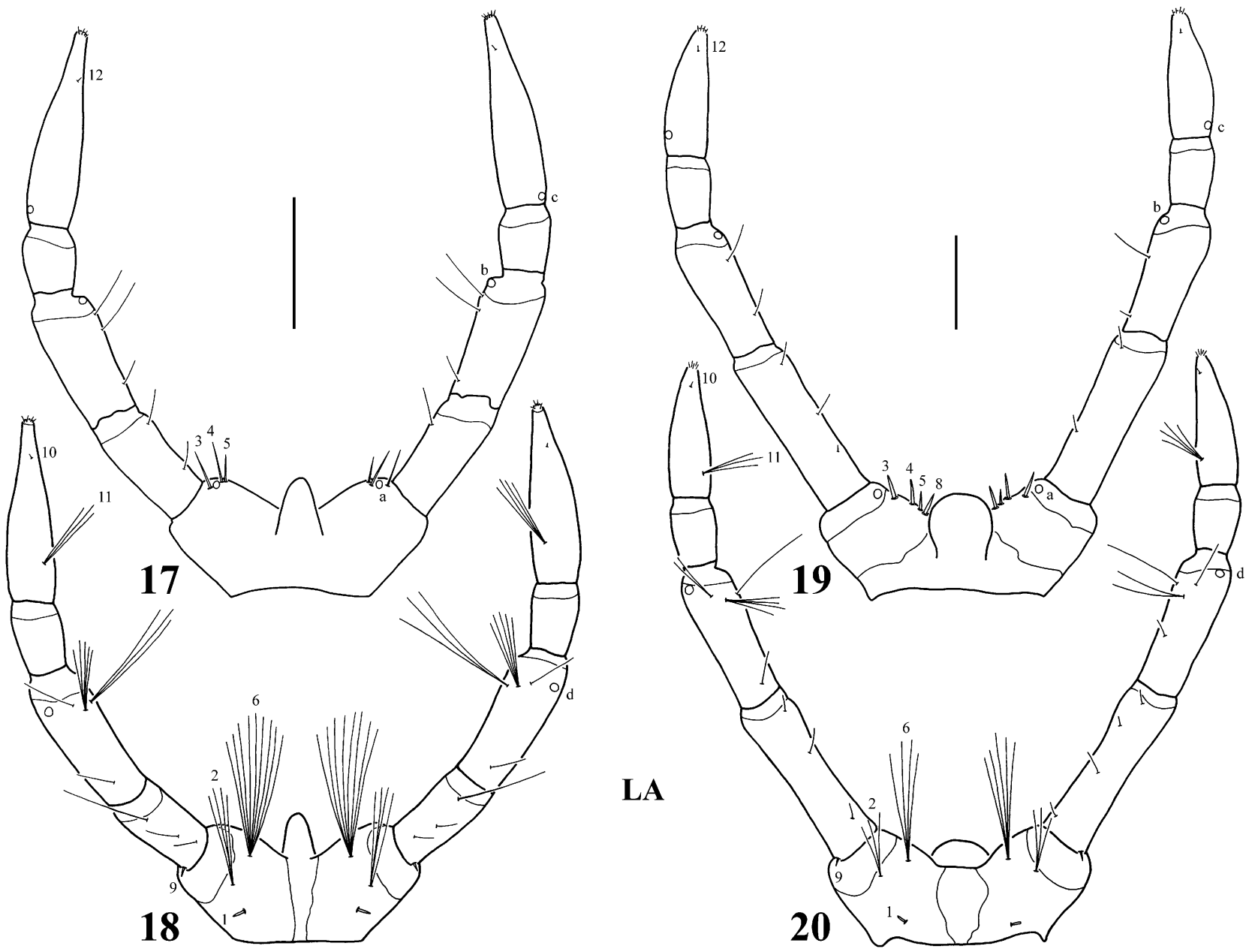

Figs 17-20. Labium of first-instar larva of species of Megadytes. 17-18 - M. carcharias: 17 - dorsal aspect; 18 - ventral aspect. 19-20 - M. fallax: 19 - dorsal aspect; 20 - ventral aspect. Scale bars $=0.15 \mathrm{~mm}$.

2001, 2003), Miller et al. (2007) and Michat (2006) but not with Ribera et al. (2008) (see also Miller, 2003). Dytiscinae was placed as sister to Matinae and close to Colymbetinae and Lancetinae. Cybistrini was also recovered as monophyletic in agreement with almost all previous results, but the sister group could not be clearly established and the tribe was resolved as part of a basal polytomy along with Aubehydrini, Dytiscini, Hydaticini, Hyderodini and the clade Aciliini + Eretini. No evidence was found of a close relationship of Cybistrini with Hydroporinae and Laccophilinae, as suggested recently based on molecular data (Ribera et al., 2008). On the other hand, the genus Megadytes was not recovered as monophyletic, with several species more related to a species of Cybister Curtis than to the subgenus Trifurcitus of Megadytes. This result agrees with previous results of Michat (2006) and Ribera et al. (2002, 2008) but not those of Miller et al. (2007), who found Megadytes and Cybister to be both monophyletic and sisters.

\section{DISCUSSION}

Larvae of Adephaga are generally characterised by the presence of a galea, with two primary setae (MX8, MX9) and two primary pores $(\mathrm{MXd}, \mathrm{MXh})$, which are deemed to be part of the ground-plan condition of the suborder (Alarie et al., 2004; Alarie \& Bilton, 2005). The galea is generally lacking within the tribe Cybistrini (Michat, 2006). However, the presence of a minute lobe-like structure in the place where the galea is commonly found, as well as the presence of the galeal sensilla in that region of the stipes in the three subgenera of Megadytes studied is of the utmost interest as it would suggest that cybistrines lost the galea secondarily. The other group of diving beetles in which most larvae lack a galea is Hydroporinae (Alarie \& Michat, 2007; Michat et al., 2007). In a recent phylogenetic analysis of the Dytiscidae based on molecular data, Ribera et al. (2008) found a close relationship of Cybistrini with Hydroporinae and Laccophilinae (larvae of this last subfamily bear a well-developed galea). However, the results presented here suggest that cybistrines are not closely related to Hydroporinae and Laccophilinae, but are well placed within Dytiscinae in agreement with the previous results of Miller (2000, 2001, 2003) and Miller et al. (2007), based on adult morphological and molecular data. Though the larvae of both Hydroporinae and Cybistrini lack a galea, the present analysis shows that, in the context of a broad cladistic analysis including numerous characters, a close relation- 


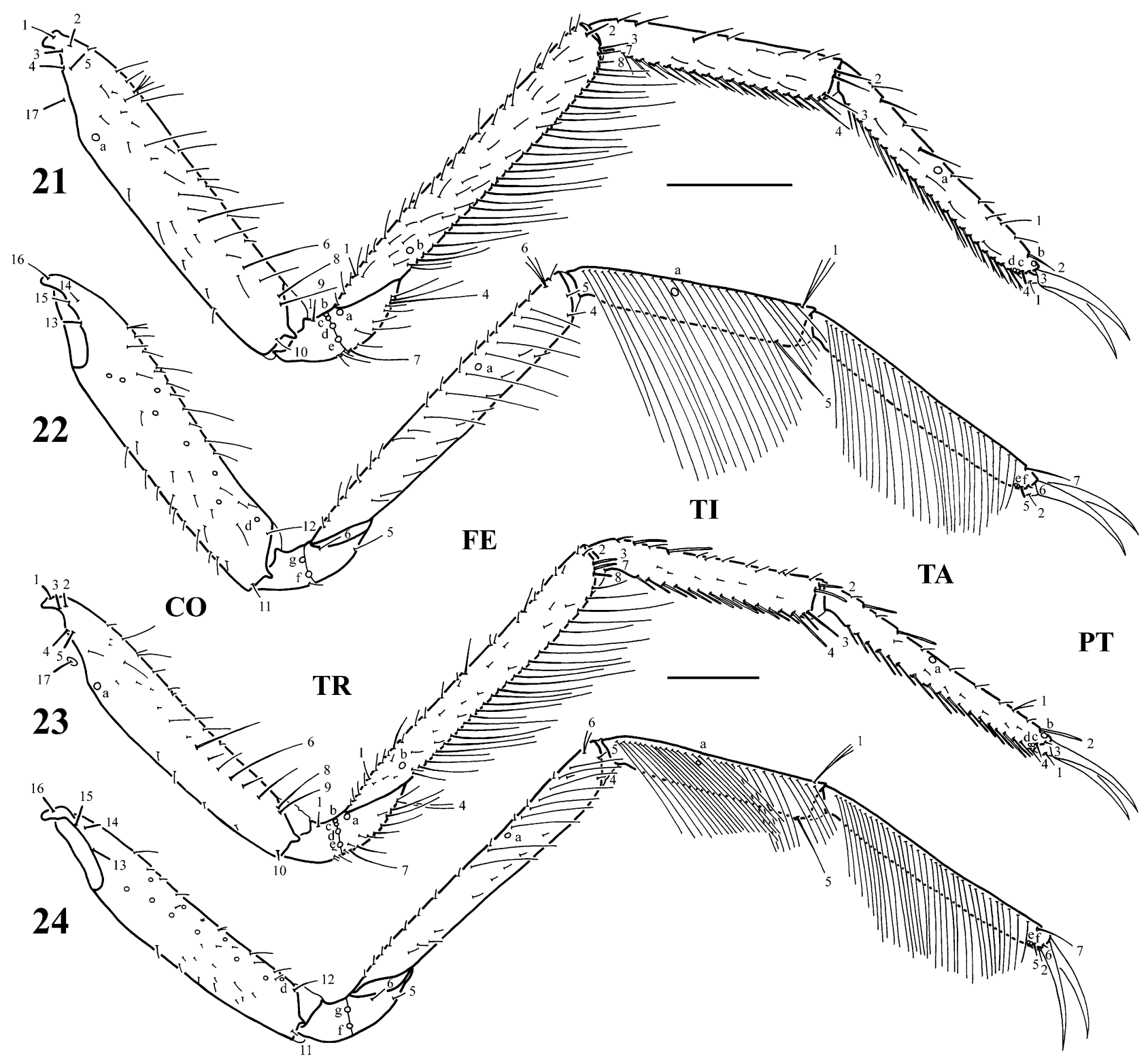

Figs 21-24. Metathoracic leg of first-instar larva of species of Megadytes. 21-22 - M. carcharias: 21 - anterior aspect; 22 - posterior aspect. 23-24-M. fallax: 23 - anterior aspect; $24-$ posterior aspect. Scale bars $=0.40 \mathrm{~mm}$.

ship between both groups seems unlikely. On the other hand, it was recently shown that larvae of some presumably ancestral hydroporines (Methlini, Laccornini, Hydrovatini, Canthyporus Zimmermann, Laccornellus Roughley \& Wolfe) have a small galea (Alarie \& Michat, 2007; Michat et al., 2007). The absence of a galea in Cybistrini thus most likely represents an independent secondary loss.

Regarding larval morphology, the subgenus Trifurcitus differs significantly in certain structures from the other three subgenera of Megadytes, among which are: (1) subtriangular head (character not included in the analysis due to its gradational nature among taxa outside Cybistrini), (2) median projection on frontoclypeus sharp apically (character 6.1), (3) lateral projections on frontoclypeus broad, flattened (character 7.1), and (4) mandibles slender, evenly curved (character 44.0) (Michat, 2006).
These differences may indicate that Trifurcitus deserves generic status, as suggested previously (Crespo, 1987; Michat, 2006). However, this is not formally proposed at this stage because: (1) recent studies of morphological and molecular data (Miller et al., 2007) support the monophyly of Megadytes including Trifurcitus; (2) low resolution and support within Cybistrini obtained in the present analysis does not allow the proper placement of Trifurcitus; (3) larvae of many species of Cybistrini are unknown and so a more comprehensive study is not possible. Future analyses combining adult and larval characters and molecular data would provide stronger evidence on the phylogenetic position of Trifurcitus.

Larval primary chaetotaxy of members of Trifurcitus is very similar to that of the subgenera Paramegadytes and Megadytes s. str. (see "Ground plan of chaetotaxy" above). This similarity apparently comprises also mem- 

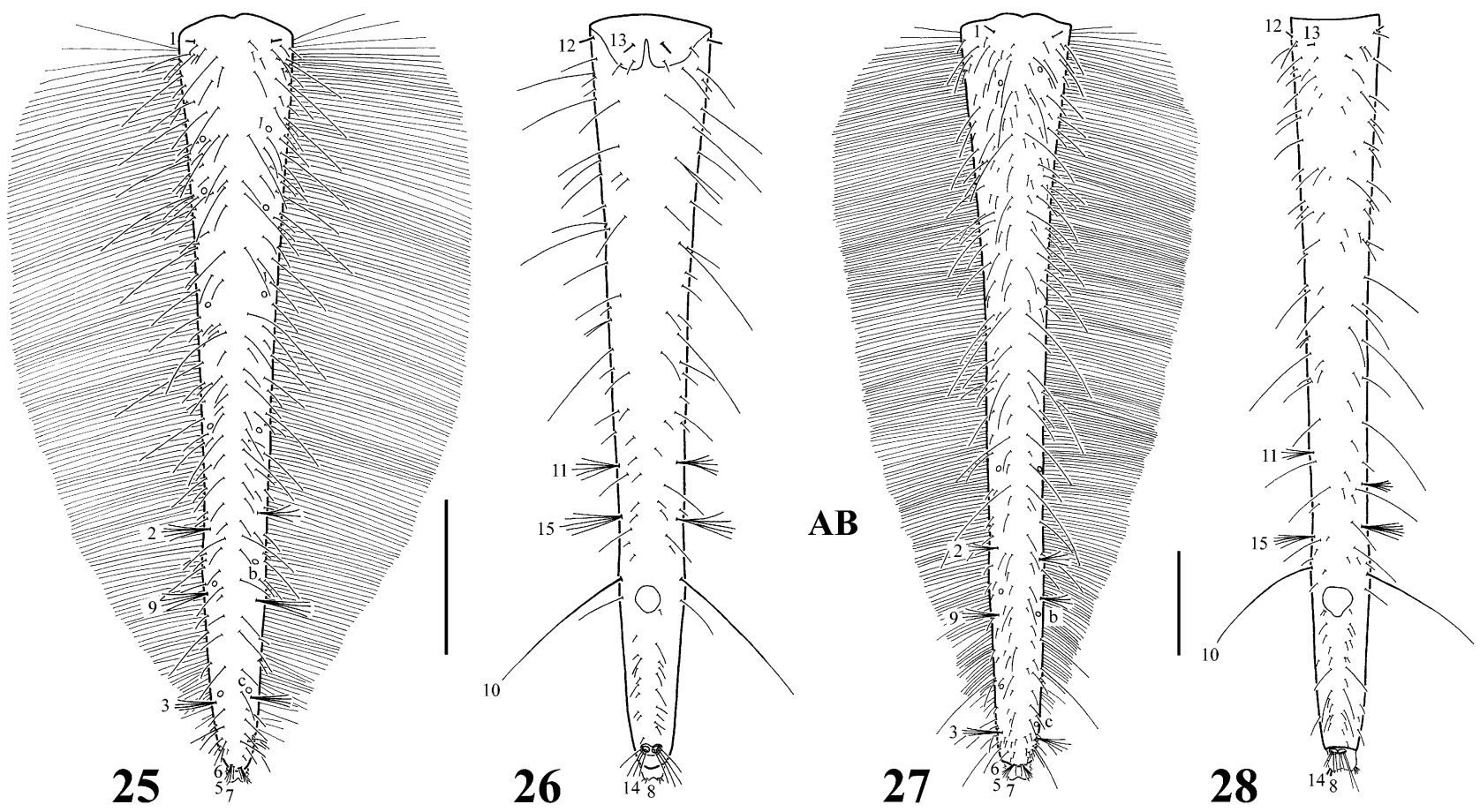

Figs 25-28. Abdominal segment VIII of first-instar larva of species of Megadytes. 25-26 - M. carcharias: 25 - dorsal aspect; 26 ventral aspect. 27-28-M. fallax: 27 - dorsal aspect; 28 ventral aspect. Scale bars $=0.70 \mathrm{~mm}$.

bers of the genus Cybister, at least when comparing the leg chaetotaxy of three Cybister species (Nilsson, 1988) with that of the Megadytes species described here (chaetotaxy of the remaining parts of the body of Cybister is not known in detail). The resemblance in larval chaetotaxy of members of Cybistrini and the fact that the primary chaetotaxy of this tribe is highly characteristic (i.e. with a large number of additional sensilla on almost every part of the body) make them a distinctive group of diving beetles. In addition to the characters mentioned in Michat (2006), several first-instar larval characters support this tribe in the present analysis including: egg bursters rounded (character 13.1), setae MX8 and MX9 and pore MXd inserted on the stipes (characters 63.2, 64.2, 66.1), presence of natatory setae on dorsal surface of tarsus (character 126.1), presence of a single pore on the urogomphus (character 158.2), and several characters related to the presence of additional (characters 39.1, 49.1, 69.1, $86.1,92.1,96.1$ ) or multibranched (characters 16.2, 60.1, $76.1,100.1,143.2,144.1)$ setae on different parts of the body. However, as first instar larvae of several of the Cybistrini species scored in the data matrix are unknown, these characters will remain as potential apomorphies until more larvae are discovered and described.

The few differences in primary chaetotaxy among the subgenera of Megadytes are summarised as follows: (1) setae on the anterior margin of frontoclypeus are simple and spiniform in Paramegadytes, Megadytes s. str. and Bifurcitus Brinck (the latter based on instar III), whereas in Trifurcitus the setae are either setiform and multibranched (M. fallax) or short and stout (M. robustus, based on instar III) (see also Michat, 2006); (2) the mandible of Paramegadytes, Megadytes s. str. and Bifurcitus bears a ring of long multi-branched setae on distal third, which is absent in Trifurcitus; (3) Paramegadytes has four setae on the anterodorsal surface of prementum, whereas Megadytes s. str. has three and Trifurcitus has two to four.

In a previous paper (Michat, 2006) the presence of a median process with bifid apex on the prementum was given as a character separating the subgenus Trifurcitus from the remaining subgenera of Megadytes. However, it was mentioned that in some specimens of M. fallax the median process is not clearly bifid but rounded apically.

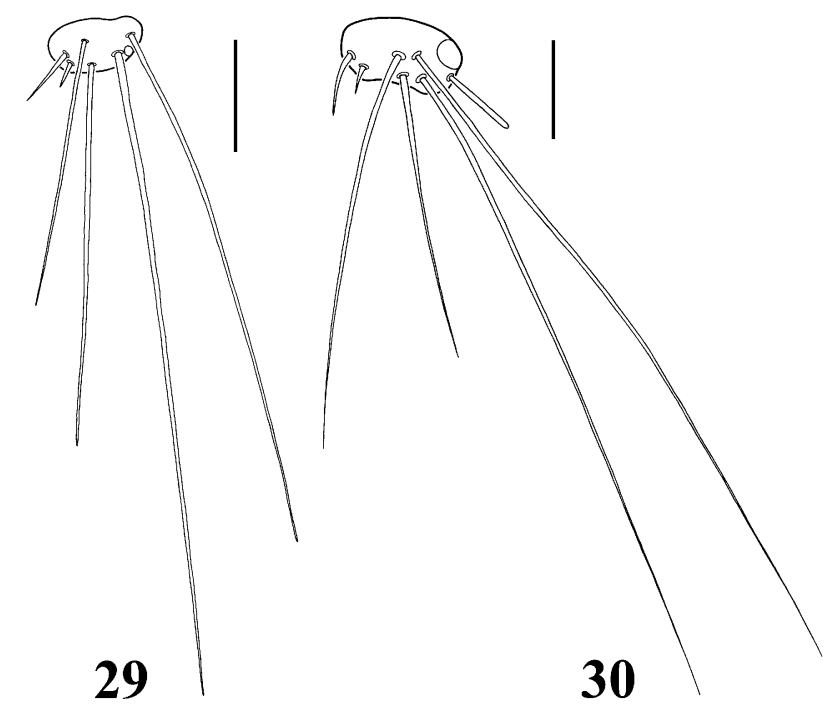

Figs 29-30. Urogomphus of first-instar larva of species of Megadytes, ventral aspect. $29-$ M. carcharias; $30-$ M. fallax. Scale bars $=0.04 \mathrm{~mm}$. 


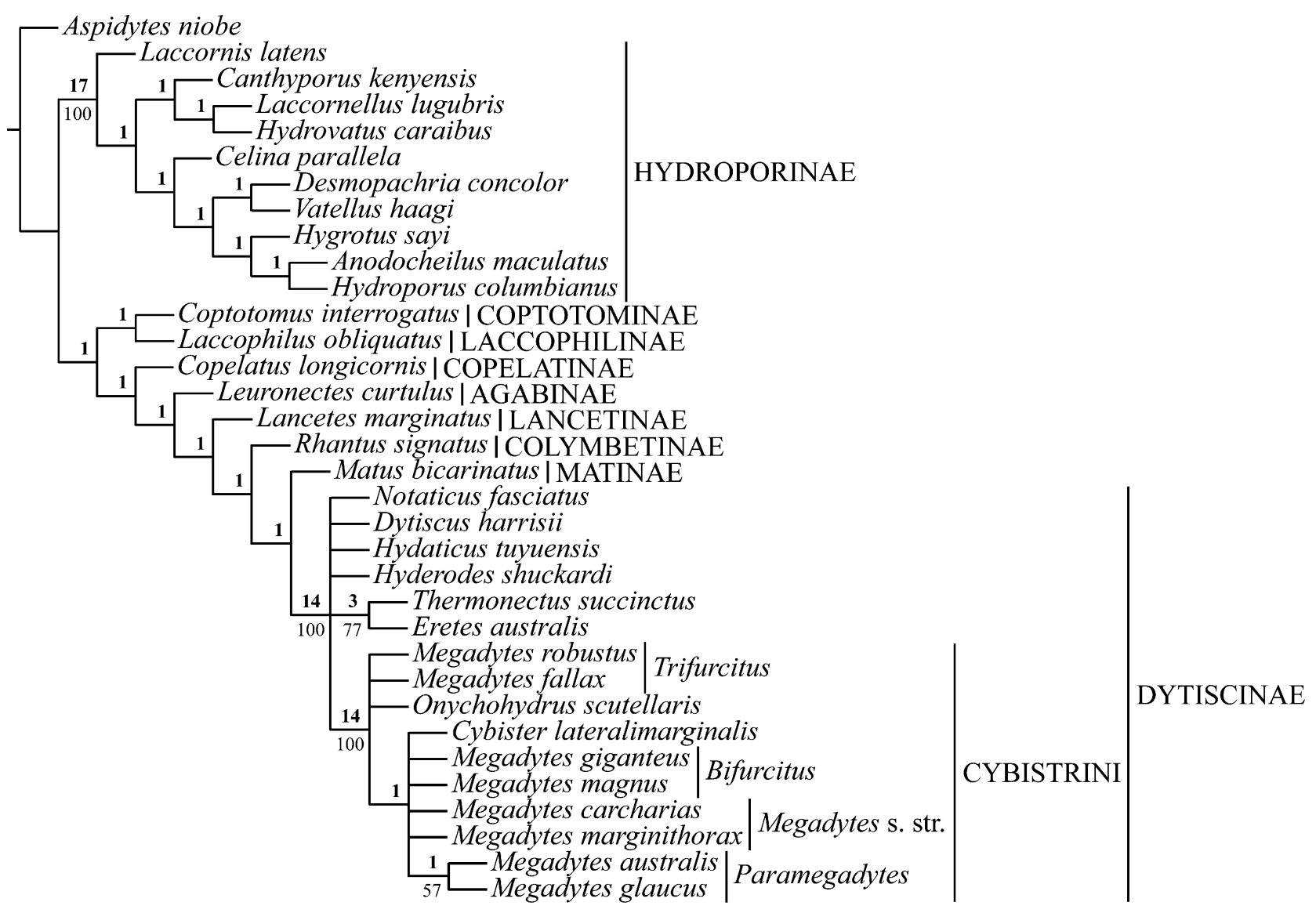

Fig. 31. Strict consensus cladogram, with Bremer support values indicated above branches and jackknife values above 50 indicated below branches.

The examination of additional material of this species indicates that the median process is rounded apically and therefore this character is not diagnostic for Trifurcitus. The presence of an apically bilobed process in $M$. robustus also needs corroboration as only one specimen of this species was studied (Michat, 2006). Accordingly, in the new data matrix character 73 (median process on prementum) is scored as state 1 (single) for both species of Trifurcitus.

Although Megadytes includes the largest known diving beetles their larvae have one of the smallest urogomphi in the entire family. In fact, urogomphal sensilla are difficult to evaluate due to the small size of this structure. In a previous paper (Michat, 2006) the presence of seven setae and one pore are reported on the urogomphus of M. glaucus. In $M$. fallax there are also seven setae and one pore, but in $M$. carcharias only six setae (and one pore) were found (character 157 in the present analysis). It is worth mentioning that the numbers of urogomphal sensilla reported for the three species are the maximum number observed in the several specimens analyzed. It is possible that some specimens actually bear fewer sensilla than those mentioned above. For example, the pore was not found in some specimens, and in others the number of setae is apparently reduced in one. However, these conclusions are not well founded because it was difficult to evaluate this character using a light microscope. The problem could be solved using scanning electron microscopy, but no additional specimens were available for such a study.

The presence of minute (non-functional) spiracles on the ventral surface of abdominal segments I-VII in instars I and II of the species described here is remarkable. A reexamination of the larvae of $M$. glaucus revealed that these spiracles are also present (overlooked in my previous paper). This finding is interesting because it is usually said that spiracles are absent in instars I and II of Dytiscidae. Due to their minute size and simple structure, however, they represent merely a fine connection of the abdominal tracheal trunks with the body wall, and are very (sometimes extremely) difficult to see. The inconspicuousness of these structures in instars I and II markedly contrasts with the well-developed (though non-funtional) spiracles of the mature larvae, and certainly they are more easily found knowing that they are located in the same place as in the third instar. These tiny spiracles were looked for in first- and second-instar larvae of different groups of Dytiscidae and were found in Hydroporinae [Celina parallela (Babington), Desmopachria concolor Sharp, Pachydrus obesus Sharp, Hydrovatus caraibus Sharp], Agabinae (Leuronectes curtulus Régimbart), Laccophilinae (Laccophilus obliquatus Régimbart) and Dytiscinae [Thermonectus succinctus (Aubé), Notaticus fasciatus Zimmermann, Hydaticus 
tuyuensis Trémouilles], suggesting that their presence is extensive within the family. They were not found in $\mathrm{Ama}$ rodytes duponti (Aubé) and instar I of Copelatus longicornis Sharp and Dytiscus harrisii Kirby, but it is not possible to say that they are absent. This character is usually used in keys separating second- (spiracles absent) from third-instar larvae (spiracles present) and I think it is still a good character. Within Cybistrini, the spiracles in instars I and II were only observed in the genus Megadytes because the larvae of the remaining genera are unknown or poorly known.

ACKNOWLEDGEMENTS. Thanks to S.A. Mazzucconi for donation of larvae of M. fallax and three anonymous referees for useful comments on the manuscript. This paper was funded by project PIP 112-200801-02759 from CONICET and project PICT-2007-01438 from ANPCyT.

\section{REFERENCES}

Alarie Y. 1989: The larvae of Laccornis Des Gozis 1914 (Coleoptera: Adepaga: Dytiscidae) with description of L. latens (Fall 1937) and redescription of L. conoideus (Leconte 1850). Coleopts Bull. 43: 365-378.

Alarie Y. 1991a: Primary setae and pores on the cephalic capsule and head appendages of larval Hydroporinae (Coleoptera: Dytiscidae). Can. J. Zool. 69: 2255-2265.

Alarie Y. 1991b: Description of larvae of 17 Nearctic species of Hydroporus Clairville (Coleoptera: Dytiscidae: Hydroporinae) with an analysis of their phylogenetic relationships. Can. Entomol. 123: 627-704.

Alarie Y. \& Bilton D.T. 2005: Larval morphology of Aspidytidae (Coleoptera: Adephaga) and its phylogenetic implications. Ann. Entomol. Soc. Am. 98: 417-430.

Alarie Y. \& Harper P.P. 1990: Primary setae and pores on the last abdominal segment and the urogomphi of larval Hydroporinae (Coleoptera: Adephaga: Dytiscidae), with notes on other dytiscid larvae. Can. J. Zool. 68: 368-374.

Alarie Y. \& Michat M.C. 2007: Phylogenetic analysis of Hydroporinae (Coleoptera: Dytiscidae) based on larval morphology, with description of first instar of Laccornellus lugubris. Ann. Entomol. Soc. Am. 100: 655-665.

Alarie Y., Harper P.P. \& Maire A. 1990a: Primary setae and pores on legs of larvae of Nearctic Hydroporinae (Coleoptera: Dytiscidae). Quaest. Entomol. 26: 199-210.

Alarie Y., Harper P.P. \& Roughley R.E. 1990b: Description of the larvae of eleven Nearctic species of Hygrotus Stephens (Coleoptera: Dytiscidae: Hydroporinae) with an analysis of their phyletic relationships. Can. Entomol. 122: 985-1035.

Alarie Y., Watts C.H.S. \& Nilsson A.N. 2001: Larval morphology of the tribe Matini (Coleoptera: Dytiscidae: Colymbetinae): descriptions of Batrachomatus daemeli, Matus bicarinatus, and Allomatus nannup and phylogenetic relationships. Can. Entomol. 133: 165-196.

Alarie Y., Beutel R.G. \& Watts C.H.S. 2004: Larval morphology of three species of Hygrobiidae (Coleoptera: Adephaga: Dytiscoidea) with phylogenetic considerations. Eur. J. Entomol. 101: 293-311.

Alarie Y., Michat M.C., Archangelsky M. \& Barber-James H.M. 2007: Larval morphology of Liodessus Guignot, 1939: generic characteristics, descriptions of five species and comparisons with other members of the tribe Bidessini (Coleoptera: Dytiscidae: Hydroporinae). Zootaxa 1516: 1-21.

Alarie Y., Michat M.C. \& WatTs C.H.S. 2009: Larval morphology of Paroster Sharp, 1882 (Coleoptera: Dytiscidae:
Hydroporinae): reinforcement of the hypothesis of monophyletic origin and discussion of phenotypic accommodation to a hypogaeic environment. Zootaxa 2274: 1-44.

BARMAN E.H. 2004: A description of the first instar larva of Coptotomus interrogatus (Fabricius) (Coleoptera: Dytiscidae: Coptotominae) with an emphasis on cranial morphology and comments on the phylogeny of basal lineages of Dytiscidae. Coleopts Bull. 58: 661-671.

Bertrand H. 1934: Notes sur quelques larves de coléoptères aquatiques. Ann. Soc. Entomol. Fr. 103: 363-382.

CRespo F.A. 1987: Los estados preimaginales de ditiscidos argentinos (Insecta-Coleoptera). Doctoral thesis, University of Buenos Aires, $184 \mathrm{pp}$.

De Marzo L. 1979: Studi sulle larve dei coleotteri ditiscidi. X. Anatomia e funzionamento dell'aparato succhinate cibariofaringeo in alcune forme larvali delle subff. Dytiscinae, Colymbetinae, Laccophilinae e Hydroporinae. Entomologica (Bari) 15: 5-72.

Ferreira N. JR. 1993: Descricáo da larva de Megadytes giganteus (Castelnau, 1834) com notas biológicas (Coleoptera: Dytiscidae). Revta Bras. Entomol. 37: 57-60.

FerReira N. JR. 1995: Description of the larvae of Megadytes fallax (Aubé) and M. marginithorax (Perty) (Coleoptera: Dytiscidae). Coleopts Bull. 49: 313-318.

Ferreira N. JR. 2000: Morfologia externa da larva de Megadytes giganteus (Laporte, 1834) (Coleoptera: Dytiscidae) e evidências sobre a condição monofilética da tribo Cybistrini. Revta. Bras. Entomol. 44: 57-69.

Ferreira N. JR., Nicolini L.B. \& Nessimian J.L. 2006: Description of the third instar larva of Megadytes latus (Fabricius) (Coleoptera, Dytiscidae), with an identification key for described larvae of the genus. Revta. Bras. Zool. 23: 792-795.

FIORI G. 1949: Contributi alla conoscenza morfologica ed etologica dei coleotteri III. Le larve dell'Acilius sulcatus L. e del Cybister lateralimarginalis De Geer (Dytiscidae). Boll. Ist. Entomol. Univ. Bologna 17: 234-264.

Goloboff P., Farris J. \& Nixon K. 2008: TNT, a free program for phylogenetic analysis. Cladistics 24: 774-786.

Kitching I.J., Forey P.L., Humphries C.J. \& Williams D.M. 1998: Cladistics, 2nd ed. The Theory and Practice of Parsimony Analysis. Systematics Association Publication No. 11. Oxford University Press, New York, 228 pp.

Meier R. \& Lim G.S. 2009: Conflict, convergent evolution, and the relative importance of immature and adult characters in Endopterygote phylogenetics. Annu. Rev. Entomol. 54: 85-104.

Michat M.C. 2006: Descriptions of larvae of Megadytes (Coleoptera: Dytiscidae: Dytiscinae): the hypothesis of monophyletic origin revisited. Eur. J. Entomol. 103: 831-842.

Мichat M.C. 2008: Description of the larvae of three species of Laccophilus Leach and comments on the phylogenetic relationships of the Laccophilinae (Coleoptera: Dytiscidae). Zootaxa 1922: 47-61.

Michat M.C. \& Alarie Y. 2009: Phylogenetic relationships of Notaticus (Coleoptera: Dytiscidae) based on larval morphology. Ann. Entomol. Soc. Am. 102: 797-808.

Michat M.C. \& ARChangelsky M. 2009: Phylogenetic relationships of Leuronectes Sharp (Coleoptera: Dytiscidae: Agabinae) based on larval morphology and chaetotaxy. Insect Syst. Evol. 40: 209-228.

Michat M.C. \& Torres P.L.M. 2005: Larval morphology of Thermonectus succinctus (Aubé 1838) (Coleoptera: Dytiscidae: Dytiscinae), with biological notes and chaetotaxic analysis. Aquat. Insects 27: 281-292.

Michat M.C. \& Torres P.L.M. 2006: Hydaticus tuyuensis Trémouilles (Coleoptera: Dytiscidae): larval morphology and 
phylogenetic relationships within Dytiscinae. Hydrobiologia 563: 479-492.

Michat M.C. \& Torres P.L.M. 2008: On the systematic position of the diving-beetle genus Pachydrus (Coleoptera: Dytiscidae: Hydroporinae): Evidence from larval chaetotaxy and morphology. Eur. J. Entomol. 105: 737-750.

Michat M.C. \& Torres P.L.M. 2009: A preliminary study on the phylogenetic relationships of Copelatus Erichson (Coleoptera: Dytiscidae: Copelatinae) based on larval chaetotaxy and morphology. Hydrobiologia 632: 309-327.

Michat M.C., Alarie Y., Torres P.L.M. \& Megna Y.S. 2007: Larval morphology of the diving beetle Celina and the phylogeny of ancestral hydroporines (Coleoptera: Dytiscidae: Hydroporinae). Invert. Syst. 21: 239-254.

Miller K.B. 2000: Cladistic analysis of the tribes of Dytiscinae and the phylogenetic position of the genus Notaticus Zimmermann (Coleoptera: Dytiscidae). Insect Syst. Evol. 31: 165-177.

Miller K.B. 2001: On the phylogeny of the Dytiscidae (Insecta: Coleoptera) with emphasis on the morphology of the female reproductive system. Insect Syst. Evol. 32: 45-92.

MiLLER K.B. 2002: Revision of the genus Eretes Laporte, 1833 (Coleoptera: Dytiscidae). Aquat. Insects 24: 247-272.

Miller K.B. 2003: The phylogeny of diving beetles (Coleoptera: Dytiscidae) and the evolution of sexual conflict. Biol. J. Linn. Soc. 79: 359-388.

Miller K.B., Bergsten J. \& Whiting M. 2007: Phylogeny and classification of diving beetles in the tribe Cybistrini (Coleoptera, Dytiscidae, Dytiscinae). Zool. Scripta 36: 41-59.

NiLSSON A.N. 1988: A review of primary setae and pores on legs of larval Dytiscidae (Coleoptera). Can. J. Zool. 66: $2283-2294$

NiLSSON A.N. 2001: World Catalogue of Insects, Vol. 3: Dytiscidae (Coleoptera). Apollo Books, Stenstrup, 395 pp.

Ribera I., Hogan J.E. \& Vogler A.P. 2002: Phylogeny of hydradephagan water beetles inferred from 18S rRNA sequences. Mol. Phyl. Evol. 23: 43-62.

Ribera I., Vogler A.P. \& Balke M. 2008: Phylogeny and diversification of diving beetles (Coleoptera: Dytiscidae). Cladistics 24: $563-590$.

Shaverdo H.V. \& Alarie Y. 2006: Description of the larva of Canthyporus kenyensis Bilardo \& Sanfilippo (Coleoptera: Dytiscidae: Hydroporinae) with implication for the phylogeny of the Hydroporini. Aquat. Insects 28: 113-130.

WatTs C.H.S. 1964: The larvae of Australian Cybister spp. Curt., Homoeodytes spp. Reg. and Hyderodes shuckardi Hope (Coleoptera: Dytiscidae). Trans. R. Soc. S. Aust. 88: 145-156.

Willey E.O. 1981: Phylogenetics. The Theory and Practice of Phylogenetic Systematics. John Wiley \& Sons, New York, $439 \mathrm{pp}$.

Received February 22, 2010; revised and accepted March 22, 2010

APPENDIX 1. Characters and states used for the cladistic analysis.

(000) Body (instars I-III): (0) not bent medially; (1) bent medially.

(001) Parietal (at level of occipital suture) (instar I): (0) not constricted; (1) constricted.

(002) Parietal (at level of occipital suture) (instars II-III): (0) not constricted; (1) constricted.

(003) Occipital suture (instar I): (0) absent; (1) present.

(004) Occipital suture (instars II-III): (0) absent; (1) present.

(005) Anterior margin of frontoclypeus (instar I): (0) rounded;

(1) deeply sinuate, with a medial projection and two lateral projections; (2) projection in form of a small horn.
(006) Medial projection on frontoclypeus (instar III): (0) absent; (1) sharp apically, with few subapical setae; (2) truncate apically, with numerous apical setae directed forward.

(007) Lateral projections on frontoclypeus (instar III): (0) absent; (1) broad, flattened, slightly projected forward; (2) not flattened, well projected forward.

(008) Lateral projections on frontoclypeus (instar III): (0) entire; (1) bilobed; (2) serrate; (3) inapplicable.

(009) Notches between medial and lateral projections on frontoclypeus (instar III): (0) absent; (1) wide to very wide; (2) very narrow.

(010) Anterolateral lobes on frontoclypeus (instars I-II): (0) absent; (1) inconspicuous; (2) well developed, not projected beyond anterior margin; (3) well developed, projected beyond anterior margin.

(011) Anterolateral lobes on frontoclypeus (instar III): (0) absent; (1) inconspicuous; (2) well developed, not projected beyond anterior margin; (3) well developed, projected beyond anterior margin.

(012) Egg bursters (instar I): (0) located submedially; (1) located basally.

(013) Shape of egg bursters (instar I): (0) spine-like; (1) rounded.

(014) Nasale (instars I-III): (0) present; (1) absent.

(015) Multi-branched setae on cephalic capsule (instar I): (0) absent; (1) present.

(016) Seta FR7 (instar I): (0) spine-like; (1) hair-like; (2) multibranched.

(017) Additional setae on surface of frontoclypeus (instar I): (0) absent; (1) present.

(018) Additional setae on anterior margin of frontoclypeus (instar I): (0) zero; (1) two; (2) at least four.

(019) Additional setae on anterior margin of frontoclypeus (instars I-III): (0) stout, rounded apically; (1) slender, sharp apically.

(020) Seta PA7 (instar I): (0) present; (1) absent.

(021) Pore PAb (instar I): (0) inserted contiguous to seta PA3;

(1) inserted far from seta PA3, close to coronal or frontal line.

(022) Pore PAl (instar I): (0) present; (1) absent.

(023) Pore PAo (instar I): (0) present; (1) absent.

(024) Pore PAp (instar I): (0) present; (1) absent.

(025) Additional dorsal setae on parietal (instar I): (0) absent; (1) present.

(026) Additional ventral setae on parietal (instar I): (0) absent;

(1) one (contiguous to PA19); (2) numerous.

(027) Secondary spine-like setae on lateral margin of parietal (instars II-III): (0) absent; (1) present.

(028) Secondary spine-like setae on ventral surface of parietal (instars II-III): (0) present; (1) absent.

(029) Ventroapical spinula on antennomere 3 (instars I-III): (0) absent; (1) small; (2) strongly developed.

(030) Apical lateroventral process on antennomere 3 (instars I-III): (0) protruding; (1) not protruding.

(031) Antennomere 4 (instar I): (0) shorter than antennomere 3; (1) subequal or somewhat longer than antennomere 3.

(032) Antennomere 1 (instars II-III): (0) not subdivided; (1) subdivided.

(033) Antennomeres 2 and 3 (instar I): (0) not subdivided; (1) subdivided.

(034) Antennomeres 2 and 3 (instar II): (0) not subdivided; (1) subdivided into two sclerites; (2) subdivided into three sclerites.

(035) Antennomeres 2 and 3 (instar III): (0) not subdivided; (1) subdivided into two sclerites; (2) subdivided into three sclerites. 
(036) Seta AN1 (instar I): (0) inserted medially or distally; (1) inserted proximally.

(037) Seta AN3 (instar I): (0) inserted distally; (1) inserted submedially.

(038) Pore ANi (instar I): (0) present; (1) absent.

(039) Additional setae on antennomeres 1 and 2 (instar I): (0) absent; (1) present.

(040) Additional ventroapical pores on antennomere 3 (instar I): (0) present; (1) absent.

(041) Secondary setae on antennomere 1 (instars II-III): (0) absent; (1) present.

(042) Secondary setae on antennomere 2 (instars II-III): (0) absent; (1) present.

(043) Mandible (instars I-III): (0) not obliquely oriented; (1) obliquely oriented.

(044) Mandible (instars I-III): (0) regularly curved; (1) distal third more strongly curved inward.

(045) Mandibular channel (instars I-III): (0) present; (1) absent.

(046) Seta MN1 (instar I): (0) distal to pore MNc; (1) proximal to pore $\mathrm{MNc}$.

(047) Sensillum MN2 (instar I): (0) hair-like; (1) pore-like.

(048) Pore $\mathrm{MNa}$ (instar I): (0) inserted at approximately the same level as pore $\mathrm{MNb}$; (1) inserted distally to pore $\mathrm{MNb}$.

(049) Additional setae on mandible (instar I): (0) absent; (1) present.

(050) Ring of long setae on distal third of mandible (instars I-III): (0) absent; (1) present.

(051) Premaxillary lobes (instars I-III): (0) reduced; (1) strongly developed, projected forward

(052) Stipes (instars I-III): (0) subtrapezoidal; subcylindrical.

(053) Galea (instars I-III): (0) well developed, subconical; (1) well developed, spine-like; (2) very short, subconical; (3) absent.

(054) Palpifer (instars I-III): (0) inconspicuous, not clearly differentiated from the stipes; (1) palpomere-like, clearly differentiated from the stipes.

(055) Maxillary palpomere 1 (instars I-III): (0) not subdivided; (1) subdivided.

(056) Maxillary palpomere 2 (instar II): (0) not subdivided; (1) subdivided.

(057) Maxillary palpomere 2 (instar III): (0) not subdivided; (1) subdivided.

(058) Maxillary palpomere 3 (instar II): (0) not subdivided; (1) subdivided into two sclerites; (2) subdivided into three sclerites.

(059) Maxillary palpomere 3 (instar III): (0) not subdivided; (1) subdivided into two sclerites; (2) subdivided into three sclerites.

(060) Setae MX1, MX2 and MX3 (instar I): (0) not multibranched; (1) multi-branched.

(061) Seta MX5 (instar I): (0) present; (1) absent.

(062) Seta MX6 (instar I): (0) present; (1) absent.

(063) Seta MX8 (instar I): (0) inserted apically on the galea; (1) inserted subapically on the galea; (2) inserted on the stipes; (3) absent.

(064) Seta MX9 (instar I): (0) inserted apically on the galea; (1) inserted subapically on the galea; (2) inserted on the stipes; (3) absent.

(065) Pore MXa (instar I): (0) present; (1) absent.

(066) Pore MXd (instar I): (0) inserted on the galea; (1) inserted on the stipes; (2) absent.

(067) Pore MXh (instar I): (0) inserted on the galea; (1) inserted on the stipes.
(068) Additional setae on the stipes (instar I): (0) absent; (1) one (contiguous to MX6); (2) row(s) of elongate spine-like setae; (3) numerous hair-like setae.

(069) Additional setae on palpifer and maxillary palpomeres 1 and 2 (instar I): (0) absent; (1) present.

(070) Secondary setae on maxillary palpomere 1 (instars II-III): (0) absent; (1) present.

(071) Prementum (instars I-III): (0) completely sclerotised; (1) with a membranous ventromedial band.

(072) Anterior margin of prementum (instar I): (0) straight to slightly emarginate; (1) deeply emarginate; (2) projected forward.

(073) Median process of prementum (instars I-III): (0) absent; (1) single; (2) deeply cleft, as two separate lobes.

(074) Labial palpomeres 1 and 2 (instar I): (0) not subdivided; (1) subdivided.

(075) Labial palpomeres 1 and 2 (instar III): (0) not subdivided; (1) subdivided.

(076) Setae LA2, LA6 and LA11 (instar I): (0) not multibranched; (1) multi-branched.

(077) Seta LA3 (instar I): (0) inserted distally or subdistally; (1) inserted proximally; (2) absent.

(078) Seta LA5 (instar I): (0) elongate, hair-like; (1) short, spine-like; (2) elongate, spine-like.

(079) Seta LA4 (instar I): (0) short, spine-like; (1) elongate, hair-like; (2) elongate, spine-like.

(080) Seta LA10 (instar I): (0) inserted submedially; (1) inserted distally; (2) absent.

(081) Setae LA10 and LA12 (instar I): (0) elongate; (1) short to very short; (2) inapplicable.

(082) Seta LA12 (instar I): (0) inserted submedially; (1) inserted distally; (2) absent.

(083) Pore LAc (instar I): (0) present; (1) absent.

(084) Additional setae on dorsal surface of prementum (instar I):

(0) absent; (1) present.

(085) Additional pore on dorsal surface of prementum (instar I): (0) absent; (1) present.

(086) Additional setae on labial palpomere 1 (instar I): (0) absent; (1) present.

(087) Secondary setae on prementum (instars II-III): (0) absent; (1) present.

(088) Secondary pores on ventral surface of prementum (instars II-III): (0) absent; (1) present.

(089) Setae on median process of prementum (instars I-III): (0) absent; (1) present; (2) inapplicable.

(090) Ventral sclerites on protórax (instars I-III): (0) absent; (1) one; (2) two.

(091) Seta CO7 on meso- and metacoxa (instar I): (0) inserted distally; (1) inserted proximally.

(092) Additional setae on coxa (instar I): (0) absent; (1) present.

(093) Additional pores on posterior surface of coxa (instar I):

(0) absent; (1) present.

(094) Seta TR2 (instar I): (0) present; (1) absent.

(095) Seta TR3 (instar I): (0) absent; (1) present.

(096) Additional setae on trochanter (instar I): (0) absent; (1) present.

(097) Seta FE1 (instar I): (0) inserted proximally; (1) inserted subproximally or submedially.

(098) Seta FE4 (instar I): (0) present; (1) absent.

(099) Seta FE5 on meso- and metafemur (instar I): (0) short, spine-like; (1) elongate, hair-like; (2) absent.

(100) Setae FE6, TI1 and TA1 (instar I): (0) not multi-branched; (1) multi-branched.

(101) Additional dorsal setae on femur (instar I): (0) absent; (1) present. 
(102) Additional posteroventral setae on femur (instar I): (0) absent; (1) present.

(103) Natatory setae on femur (instar I): (0) absent; (1) present.

(104) Natatory dorsal setae on femur (instars II-III): (0) absent; (1) present.

(105) Natatory ventral setae on femur (instars II-III): (0) absent; (1) present.

(106) Secondary anterodorsal setae on femur (instars II-III): (0) absent; (1) present.

(107) Secondary posteroventral setae on femur (instars II-III) (0) absent; (1) present.

(108) Seta TI1 (instar I): (0) inserted distally; (1) inserted subdistally or submedially.

(109) Seta TI4 (instar I): (0) more proximal on leg 1; (1) not more proximal on leg $1 ;(2)$ absent.

(110) Seta TI5 (instar I): (0) spine-like; (1) hair-like.

(111) Seta TI6 on pro- and mesotibia (instar I): (0) elongate, hair-like; (1) short, spine-like.

(112) Seta TI6 on metatibia (instar I): (0) elongate, hair-like; (1) short, spine-like.

(113) Seta TI7 (instar I): (0) short, spine-like; (1) elongate, hairlike.

(114) Additional anterodorsal setae on tibia (instar I): (0) absent; (1) present.

(115) Additional anteroventral setae on tibia (instar I): (0) absent; (1) present.

(116) Secondary setae on tibia (instars II-III): (0) absent; (1) present.

(117) Natatory dorsal setae on tibia (instar I): (0) absent; (1) present.

(118) Natatory dorsal setae on tibia (instars II-III): (0) absent; (1) present.

(119) Natatory ventral setae on protibia (instars I-III): (0) absent; (1) present.

(120) Natatory ventral setae on meso- and metatibia (instars I-III): (0) absent; (1) present.

(121) Seta TA1 (instar I): (0) short to very short; (1) elongate to very elongate; (2) absent.

(122) Additional anteroventral setae on tarsus (instar I): (0) absent; (1) present.

(123) Secondary setae on anterodorsal margin of protarsus (instars II-III): (0) absent; (1) present.

(124) Secondary setae on posteroventral margin of protarsus (instar III): (0) absent; (1) present.

(125) Secondary setae on posteroventral margin of metatarsus (instar III): (0) absent; (1) present.

(126) Natatory dorsal setae on tarsus (instar I): (0) absent; (1) present.

(127) Natatory dorsal setae on tarsus (instars II-III): (0) absent; (1) present.

(128) Natatory ventral setae on tarsus (instars II-III): (0) absent; (1) present.

(129) Basoventral patch of dense slender spinulae on protarsus (instars I-III): (0) absent; (1) present.

(130) Basoventral spinulae on claws (instar I): (0) absent; (1) present.

(131) Basoventral spinulae on claws (instars II-III): (0) absent; (1) present.

(132) Abdominal tergites I-VI (instars I-III): (0) well developed; (1) reduced.

(133) Abdominal tergites I-VI (instar I): (0) with anterotransverse carina; (1) without anterotransverse carina.

(134) Ventral surface of abdominal segments II-VI (instar III): (0) membranous; (1) sclerotised.

(135) Ventral surface of abdominal segment VI (instars I-II): (0) membranous; (1) sclerotised.
(136) Abdominal segment VII (instar I): (0) sclerotised dorsally, membranous ventrally; (1) completely sclerotised except for a narrow, longitudinal, ventral band; (2) sclerotised dorsally and ventrally, with ventral sclerite independent from dorsal sclerite; (3) completely sclerotised.

(137) Abdominal segment VII (instars II-III): (0) membranous ventrally; (1) sclerotised ventrally.

(138) Abdominal sclerite VII (instar I): (0) with anterotransverse carina; (1) without anterotransverse carina.

(139) Abdominal segment VII (instar I): (0) without lateral row of natatory setae; (1) with lateral row of natatory setae.

(140) Abdominal segment VII (instars II-III): (0) without lateral row of natatory setae; (1) with lateral row of natatory setae.

(141) Abdominal segment VIII (instars I-III): (0) completely sclerotised; (1) completely sclerotised except ventrodistally around the anus.

(142) Siphon (instars I-III): (0) very short; (1) short to moderately elongate; (2) very elongate, urogomphomere-like; (3) absent.

(143) Sensillum AB2 (instar I): (0) hair-like; (1) pore-like; (2) multi-branched; (3) absent.

(144) Seta AB3 (instar I): (0) not multi-branched; (1) multibranched.

(145) Seta AB9 (instar I): (0) inserted dorsolaterally; (1) inserted ventrolaterally.

(146) Seta AB11 (instar I): (0) spine-like; (1) hair-like; (2) multi-branched.

(147) Seta AB11 (instar I): (0) inserted contiguous to ventroapical margin; (1) inserted far from ventroapical margin.

(148) Seta AB15 (instar I): (0) absent; (1) inserted contiguous to ventroapical margin; (2) inserted far from ventroapical margin.

(149) Pore ABc (instar I): (0) present; (1) absent.

(150) Additional setae on abdominal segment VIII (excluding natatory setae) (instar I): (0) absent; (1) one spine-like seta inserted on lateral margin; (2) numerous.

(151) Additional dorsal pores on abdominal segment VIII (instar I): (0) absent; (1) present.

(152) Natatory setae on lateral margin of abdominal segment VIII (instar I): (0) absent; (1) present.

(153) Natatory setae on lateral margin of abdominal segment VIII (instars II-III): (0) absent; (1) present.

(154) Multi-branched setae on abdominal segment VIII (instar I): (0) absent; (1) present.

(155) Urogomphus (instars I-III): (0) well developed; (1) minute.

(156) Urogomphus (instars I-III): (0) composed of one urogomphomere; (1) composed of two urogomphomeres.

(157) Number of primary setae on urogomphus (excluding natatory setae) (instar I): (0) nine; (1) eight; (2) six-seven; (3) numerous.

(158) Number of primary pores on urogomphus (instar I): (0) three or more; (1) two; (2) one.

(159) Setae UR2, UR3 and UR4 (instar I): (0) inserted contiguously; (1) not inserted contiguously; (2) only UR2 and UR3 contiguous; (3) only UR3 and UR4 contiguous.

(160) Seta UR5 (instar I): (0) elongate, hair-like; (1) short, spine-like.

(161) Seta UR6 (instar I): (0) elongate; (1) short.

(162) Seta UR7 (instar I): (0) elongate, hair-like; (1) short, spine-like.

(163) Seta UR8 (instar I): (0) inserted terminally on urogomphomere 2; (1) inserted subapically on urogomphomere 2 ; (2) inserted submedially on urogomphomere $2 ;(3)$ inserted proximally on urogomphomere 2 ; (4) absent; (5) inserted on urogomphomere 1 . 


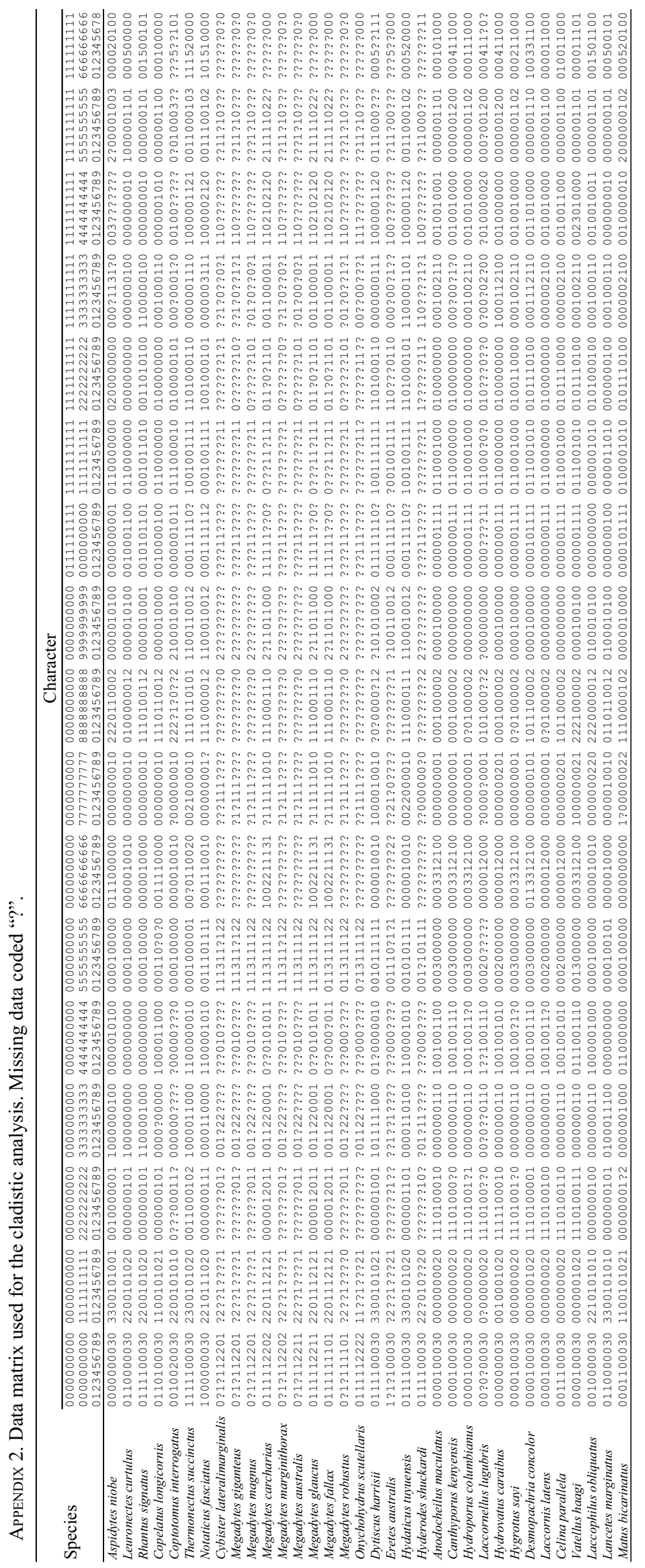

(164) Pore URb (instar I): (0) proximal to seta UR2; (1) contiguous to seta UR2; (2) distal to seta UR2; (3) absent.

(165) Pore URc (instar I): (0) not inserted terminally on urogomphomere 1; (1) inserted terminally on urogomphomere 1.

(166) Secondary setae on urogomphus (instars II-III): (0) absent; (1) present.

(167) Row of natatory setae on urogomphus (instar I): (0) absent; (1) present.

(168) Row of natatory setae on urogomphus (instars II-III): (0) absent; (1) present. 